\title{
Spatial distribution of Batrachochytrium dendrobatidis in South American caecilians
}

\author{
Carolina Lambertini ${ }^{1, *}$, C. Guilherme Becker ${ }^{2}$, Cecilia Bardier $^{1,3}$, \\ Domingos da Silva Leite ${ }^{4}$, Luís Felipe Toledo ${ }^{1}$
}

\footnotetext{
${ }^{1}$ Laboratório de História Natural de Anfíbios Brasileiros (LaHNAB), Departamento de Biologia Animal, Instituto de Biologia, Universidade Estadual de Campinas, Campinas, São Paulo 13083-862, Brazil

${ }^{2}$ Departamento de Zoologia, Universidade Estadual Paulista, Rio Claro, São Paulo 13506-900, Brazil

${ }^{3}$ Laboratorio de Sistemática e Historia Natural de Vertebrados, Instituto de Ecología y Ciencias ambientales, Universidad de la República, Montevideo 11400, Uruguay

${ }^{4}$ Departamento de Genética, Evolução e Bioagentes, Instituto de Biologia, Universidade Estadual de Campinas, Campinas, São Paulo 13083-862, Brazil
}

\begin{abstract}
The amphibian-killing fungus Batrachochytrium dendrobatidis $(B d)$ is linked to population declines in anurans and salamanders globally. To date, however, few studies have attempted to screen $B d$ in live caecilians; $B d$-positive caecilians have only been reported in Africa and French Guiana. Here, we performed a retrospective survey of museum preserved specimens to (1) describe spatial patterns of $B d$ infection in Gymnophiona across South America and (2) test whether areas of low climatic suitability for $B d$ in anurans predict $B d$ spatial epidemiology in caecilians. We used quantitative PCR to detect $B d$ in preserved caecilians collected over a $109 \mathrm{yr}$ period, and performed autologistic regressions to test the effect of bioclimatic metrics of temperature and precipitation, vegetation density, and elevation on the likelihood of $B d$ occurrence. We detected an overall $B d$ prevalence of $12.4 \%$, with positive samples spanning the Uruguayan savanna, Brazil's Atlantic Forest, and the Amazon basin. Our autologistic models detected a strong effect of macroclimate, a weaker effect of vegetation density, and no effect of elevation on the likelihood of $B d$ occurrence. Although most of our $B d$-positive records overlapped with reported areas of high climatic suitability for the fungus in the Neotropics, many of our new $B d$-positive samples extend far into areas of poor suitability for $B d$ in anurans. Our results highlight an important gap in the study of amphibian chytridiomycosis: the potential negative impact of $B d$ on Neotropical caecilians and the hypothetical role of caecilians as $B d$ reservoirs.
\end{abstract}

KEY WORDS: Chytrid infection dynamics · Gymnophiona $\cdot$ Life history · Environmental variables · Museum specimens

Resale or republication not permitted without written consent of the publisher

\section{INTRODUCTION}

Amphibian fungal pathogens of the genus Batrachochytrium are linked to global population declines in anurans and salamanders through the infectious disease chytridiomycosis (Berger et al. 1998, Lips et al. 2008, Martel et al. 2013). The amphibian-killing fungus Batrachochytrium dendrobatidis $(B d)$ has been acknowledged as one of the most destructive patho- gens to wildlife (Fisher \& Garner 2007, Skerratt et al. 2007), causing population declines in a large fraction of infected species. $B d$ is a host-generalist pathogen among amphibians (Valencia-Aguilar et al. 2015), infecting anurans and salamanders from tropical and temperate regions (Lips et al. 2006, 2008, Vredenburg et al. 2010, Cheng et al. 2011). Reports of $B d$ infection in caecilians (Gymnophiona), however, are rare in the literature. To our knowledge, only 4 
reports of $B d$ from wild-caught caecilians are available to date (Doherty-Bone et al. 2013, Gower et al. 2013, Hydeman et al. 2013, Rendle et al. 2015).

The first study screening for $B d$ in caecilians reported 53 Bd-positive caecilians out of 85 tested individuals from Cameroon (Doherty-Bone et al. 2013). In the same year, Gower et al. (2013) reported the first case of lethal chytridiomycosis in caecilians from Cameroon and Tanzania. They reported that wild-caught specimens of Geotrypetes seraphini that tested positive for $B d$ died in captivity with signs of chytridiomycosis. $B d$ infections were also confirmed in an endemic caecilian (Schistometopum thomense) from an island of the archipelago of São Tomé and Príncipe (Hydeman et al. 2013). The only record of $B d$ infecting caecilians outside Africa was recently published for a wild-caught specimen from French Guiana (Rendle et al. 2015). Despite the observed high $B d$ prevalence in African caecilians, sampling efforts to detect $B d$ in Gymnophiona have been made in other regions but without any $B d$-positive samples from specimens collected in the wild in peninsular Malaysia ( $\mathrm{n}=2$; Savage et al. 2011), Colombia ( $\mathrm{n}=1$; VásquezOchoa et al. 2012), West Africa ( $\mathrm{n}=6$; Penner et al. 2013), and the Seychelles archipelago ( $\mathrm{n}=78$; Labisko et al. 2015). The small sample sizes of these published reports reflect the difficulty and/or lack of effort in working with this generally inconspicuous taxon (e.g. Gower \& Wilkinson 2005); thus, it cannot be ruled out that Gymnophiona are infected with $B d$ as extensively as anurans are. Furthermore, conspicuous die-offs due to chytridiomycosis, such as those observed in anurans, are relatively unlikely to be observed in caecilians (Gower et al. 2013) due to their fossorial or fully aquatic life styles (Wells 2007 , Vitt \& Caldwell 2014). Caecilians are broadly distributed in the tropics (Taylor 1968, Frost 2016), often co-occurring with anuran populations heavily impacted by chytridiomycosis (Seimon et al. 2007, Gower et al. 2012, Bataille et al. 2013, James et al. 2015) and inhabiting microhabitats within $B d$ 's optimal growth conditions of temperature and humidity (Piotrowski et al. 2004). Determining whether caecilians are affected by chytridiomycosis as much as anurans and salamanders are, and whether caecilians are serving as pathogen reservoirs, is relevant for amphibian conservation (Gower \& Wilkinson 2005).

Several environmental factors influence $B d$ infection in anurans. Infection prevalence and zoospore loads are often positively correlated with elevation (Brem \& Lips 2008, Gründler et al. 2012, Catenazzi et al. 2013), vegetation density (Puschendorf et al. 2009, Becker \& Zamudio 2011, Becker et al. 2016), and precipitation (Becker \& Zamudio 2011), and negatively correlated with temperature (Becker \& Zamudio 2011, Ruggeri et al. 2015, Becker et al. 2016). Because most caecilians are fossorial, they are likely exposed to lower microclimatic fluctuations dictated by land cover, insolation, and humidity. Therefore, microclimatic optima/averages for caecilians might fall within the optimal growth conditions of $B d$, allowing $B d$ to persist in areas where it would otherwise not endure year-round.

Here, we performed a retrospective survey of museum preserved specimens to (1) describe spatial patterns of $B d$ infection in Gymnophiona in South America and (2) test whether areas of low climatic suitability for $B d$ in anurans predict spatial epidemiology of $B d$ in caecilians. We used quantitative PCR to detect $B d$ in preserved caecilians collected over a 109 yr period, and performed autologistic regressions to test the effect of bioclimatic metrics of temperature and precipitation, vegetation density, and elevation on the likelihood of $B d$ occurrence. Our results provide novel information on $B d$ spatial epidemiology and suggest that caecilians could be potentially threatened or serve as $B d$ reservoirs in regions where anurans are not infected during most of the year.

\section{MATERIALS AND METHODS}

\section{Species sampling}

We sampled 193 museum-preserved specimens of Gymnophiona: 160 from Brazil (Caeciliidae, Siphonopidae, and Typhlonectidae) and 33 from Uruguay (Typhlonectidae; Table 1). We screened specimens from 3 out of 4 South American caecilian families housed at the following herpetological collections: Museu Paraense Emílio Goeldi (MPEG), Museu de Zoologia prof. Adão José Cardoso, Universidade Estadual de Campinas (ZUEC), Museu Nacional, Universidade Federal do Rio de Janeiro (MNRJ), Coleção de Anfíbios Célio F. B. Haddad, Universidade Estadual Paulista (CFBH), and Colección de Vertebrados de la Universidad de La Republica, Montevideo (ZVCB) (see Table S1 in the Supplement at www.int-res.com/articles/suppl/d124p109_supp.pdf). For standardization purposes, we did not include in our analyses published $B d$ data from wild-caught caecilians from French Guiana, Guyana, and Colombia (Vásquez-Ochoa et al. 2012, Gower et al. 2013, Rendle et al. 2015). We gathered GPS coordinates in 
Table 1. Families, species, environment, and country where individual caecilians were captured, and proportion of animals infected by Batrachochytrium dendrobatidis (as the number of positives/total number screened). All species were collected in Brazil, apart from C. indistinctum (collected in Uruguay)

\begin{tabular}{|c|c|c|c|}
\hline Family & Habit & Habitat & $\begin{array}{c}\text { Proportion } \\
\text { infected }\end{array}$ \\
\hline \multicolumn{4}{|l|}{ Caeciliidae } \\
\hline Caecilia gracilis & Fossorial & Rainforest & $0 / 1$ \\
\hline \multicolumn{4}{|l|}{ Siphonopidae } \\
\hline Luetkenotyphlus brasiliensis & Fossorial & Rainforest & $3 / 9$ \\
\hline Siphonops annulatus & Fossorial & Rainforest & $1 / 12$ \\
\hline Siphonops cf. annulatus & Fossorial & Rainforest & $1 / 1$ \\
\hline Siphonops paulensis & Fossorial & Rainforest & $2 / 8$ \\
\hline Siphonops cf. paulensis & Fossorial & $\begin{array}{r}\text { Rainforest, } \\
\text { Grassland }\end{array}$ & $0 / 15$ \\
\hline Siphonops sp. (aff. paulensis) & Fossorial & Grassland & $0 / 2$ \\
\hline Siphonops hardyi & Fossorial & Rainforest & $0 / 2$ \\
\hline Siphonops sp. & Fossorial & $\begin{array}{r}\text { Rainforest, } \\
\text { Grassland }\end{array}$ & $1 / 7$ \\
\hline \multicolumn{4}{|l|}{ Typhlonectidae } \\
\hline Atretochoana eiselti & Aquatic & Rainforest & $0 / 4$ \\
\hline Chthonerpeton braestrupi & Aquatic & Rainforest & $0 / 6$ \\
\hline Chthonerpeton indistinctum & Aquatic & Grassland & $4 / 33$ \\
\hline Chthonerpeton indistinctum & Aquatic & Rainforest & $0 / 1$ \\
\hline Chthonerpeton noctinetes & Aquatic & Rainforest & $0 / 8$ \\
\hline Chthonerpeton sp. & Aquatic & Rainforest & $0 / 1$ \\
\hline Chthonerpeton tremembe & Aquatic & Grassland & $0 / 4$ \\
\hline Chthonerpeton viviparum & Aquatic & Rainforest & $0 / 8$ \\
\hline Potamotyphlus kaupii & Aquatic & Rainforest & $9 / 39$ \\
\hline Typhlonectes compressicauda & Aquatic & Rainforest & $3 / 32$ \\
\hline Total & & & $24 / 193$ \\
\hline
\end{tabular}

decimal degrees for each sampled specimen based on museum data. We used the geographic centroid of municipalities as an approximation when precise geographic coordinates were not available. We did not consider records of $B d$ from captive and live specimens for methodological consistency (e.g. Raphael \& Pramuk 2007, Churgin et al. 2013).

\section{$B d$ detection}

Retrospective sampling of museum specimens has been widely used to determine historical dynamics of $B d$ across space and time (Weldon et al. 2004, Ouellet et al. 2005, Soto-Azat et al. 2010, Cheng et al. 2011, Rodriguez et al. 2014, Courtois et al. 2015, Talley et al. 2015, Becker et al. 2016). We swabbed individual specimens on the head, anal disc, and dorsal and ventral surfaces with a single swab per individual, following Rendle et al. (2015), and stored each sample in a $1.5 \mathrm{ml}$ dry sterile tube. We extracted DNA from each swab using $50 \mu \mathrm{l}$ PrepMan ULTRA ${ }^{\circledR}$ and proceeded with molecular detection with the TaqMan ${ }^{\circledR}$ qPCR assay (Life Technologies), using strain CLFT 023 as a quantitative standard for the reactions diluted from $10^{3}$ to $10^{-1}$ zoospore genomic equivalents (GE; Boyle et al. 2004, Lambertini et al. 2013). We considered Bd-positive samples with $\mathrm{GE} \geq 1$ (Kriger et al. 2007).

\section{Statistical analyses}

We described patterns of $B d$ infection in Caecilians from Brazil and Uruguay (proportion of $B d$-infected individuals \pm binomial $95 \%$ CI). We classified species based on their predominant life history (aquatic or fossorial) and reported the proportion ( \pm binomial $95 \%$ CI) of infected individuals for each lifehistory category and ecoregion. We also described spatiotemporal patterns of $B d$ infections from 1905 to $2014 ; 28$ specimens lacking information for their collection year were excluded from these calculations.

Furthermore, we conducted multi-model inference using autologistic regressions to test for the effect of bioclimatic variables, vegetation density, and elevation on the likelihood of $B d$ infection while accounting for the effects of spatial autocorrelation (Rangel et al. 2010). For each sampling location, we extracted 19 bioclimatic variables of temperature and precipitation averaged over a period of $50 \mathrm{yr}$ (Hijmans et al. 2005), vegetation density (FAO 2010), and elevation, using Arc Map v.10.1 (ESRI). We used a model averaging procedure, including $B d$ as the response variable (presence vs. absence) and the aforementioned environmental factors as explanatory variables. Our model averaging ranked all possible models based on Akaike's information criterion (AIC) and averaged beta coefficients of variables present in $90 \%$ of models within $\Delta \mathrm{AIC}<2$. We reported the strength and the direction that each environmental variable influenced $B d$. We used SAM v4.0 to perform spatial statistics (Rangel et al. 2010).

\section{RESULTS}

Our qPCR reactions detected $B d$ in 24 out of 193 screened specimens $(12.4 \%, 95 \% \mathrm{CI}=0.08-0.17$; Fig. 1). Infected individuals belonged to the families 


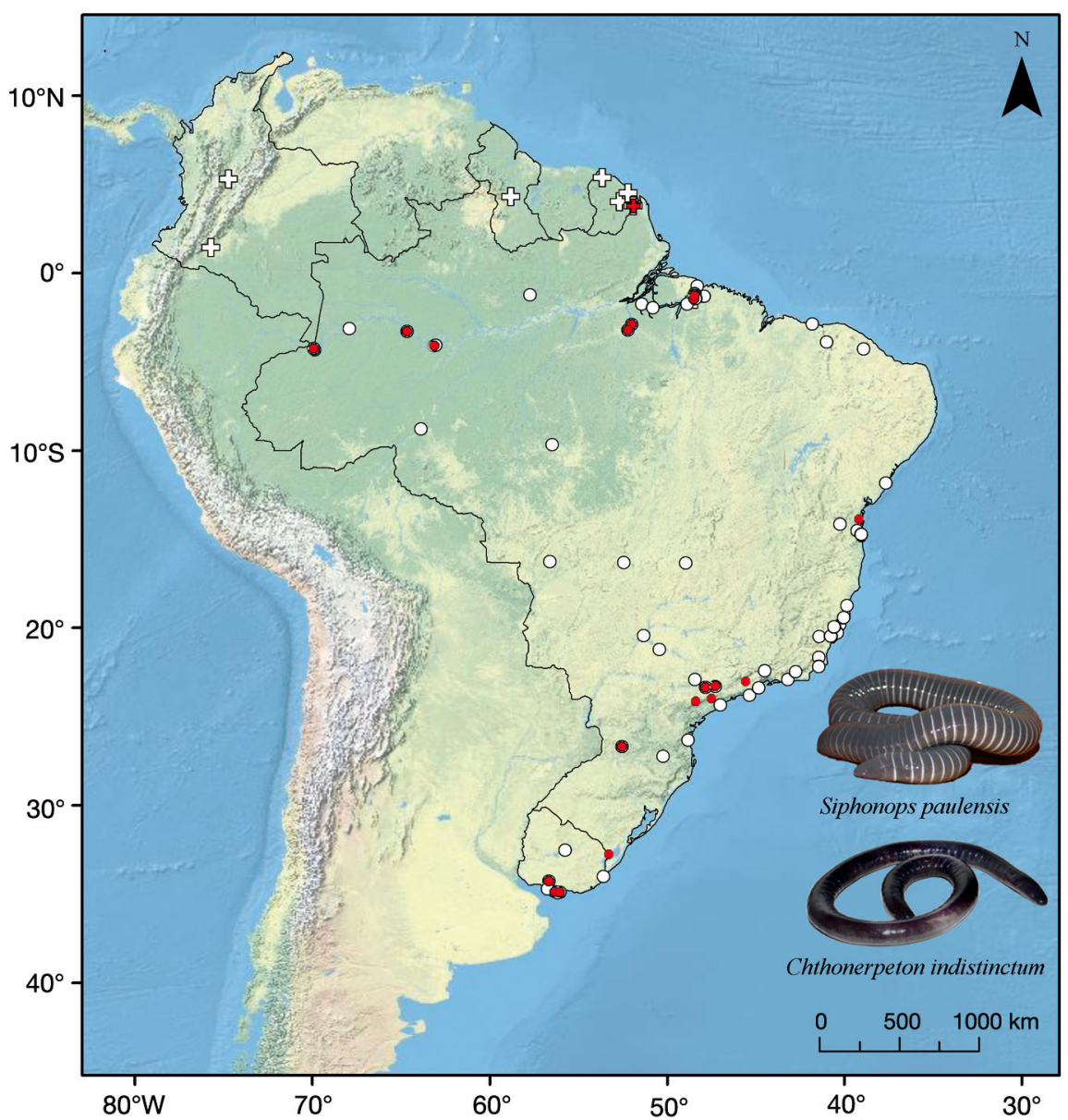

Fig. 1. Batrachochytrium dendrobatidis sampling in museum-preserved caecilians from Brazil and Uruguay (positive samples: red circles; negative samples: white circles), and wild-caught caecilians (positive sample: red cross; negative samples: white crosses; Vásquez-Ochoa et al. 2012, Gower et al. 2013, Rendle et al. 2015, present study). Siphonops paulensis is a fossorial terrestrial species found in eastern Brazil, and Chthonerpeton indistinctum is an aquatic species that is the only caecilian species found in Uruguay. Photographs: Daniel Loebmann. Service layer source: US National Park Service
Siphonopidae ( $\mathrm{n}=8$ individuals) and Typhlonectidae ( $\mathrm{n}=16$ ) distributed across the Uruguayan savanna (proportion of infected individuals $=12.1 \%$, $95 \% \mathrm{CI}=0.03-0.28, \mathrm{n}=33$ total individuals sampled), the Amazon Basin (16\%, $95 \% \mathrm{CI}=0.08-0.26$, $\mathrm{n}=75$ ), and Brazil's Atlantic Forest (13.5\%, $95 \%$ $\mathrm{CI}=0.06-0.24, \mathrm{n}=59$ ). We did not detect $B d$ in individuals of Caeciliidae or in samples from the Brazilian Cerrado, Caatinga, and Pantanal, but our sampling sizes in these ecoregions were small ( $\mathrm{n}=$ 2,22 , and 2 , respectively). We detected a proportion of infected individuals of $11.7 \%$ in aquatic species (95\% CI $=0.06-0.18, \mathrm{n}=136)$ and $14 \%$ in terrestrial (typically fossorial) species $(95 \% \mathrm{CI}=0.06-$ $0.25, \mathrm{n}=57$ ).

Although our sampling spanned $109 \mathrm{yr}$, most of our $B d$-positive specimens $(\mathrm{n}=16)$ were collected after 1994. Only 5 samples before this period tested positive for $B d$, and were collected from the wild between 1965 and 1994, and 3 positive samples had no collecting date. However, 21 samples known to have been collected prior to 1971 were screened, and they all tested negative for $B d$.
Our spatial regression models indicated a significant effect of macroclimate on the likelihood of $\mathrm{Bd}$ occurrence (Table 2). Our autologistic model averaging showed a negative effect of maximum temperature of the warmest month and precipitation in the wettest quarter, and a positive effect of annual precipitation on $B d$ infection likelihood; the full set of significant variables is provided in Table 2. Vegetation density had a weak negative effect on $B d$ occurrence, and elevation was not a significant variable in our models (Table 2, Table S2).

\section{DISCUSSION}

Seasonal variations in temperature and precipitation strongly mediate $B d$ infections by changing optimal physiological conditions of hosts and pathogen (Piotrowski et al. 2004, Becker \& Zamudio 2011, Ruggeri et al. 2015). These environmental constraints are revealed in several environmental niche models, indicating that much of South America is unsuitable for $B d$ during at least part of the year 
Table 2. Model averaging results ranking significant environmental variables explaining Batrachochytrium dendrobatidis occurrence in South American caecilians. Rank importance corresponds to the number of models in which each variable was present (also see Table S2 in the Supplement). CI: confidence interval. Bio 3: isothermality, Bio 5: temperature of warmest month, Bio 9: mean temperature of driest quarter, Bio 10: mean temperature of warmest quarter, Bio 12: annual precipitation, Bio 13: precipitation of wettest month, Bio 14: precipitation pf driest month, Bio 15: precipitation seasonality, Bio 16: precipitation of wettest quarter, Bio 17: precipitation of driest quarter, Bio 18: precipitation of warmest quarter, Bio 19: precipitation of coldest quarter

\begin{tabular}{|lcrc|}
\hline Variable & $\begin{array}{c}\text { Rank } \\
\text { importance }\end{array}$ & $\begin{array}{c}\text { Beta } \\
\text { coefficient }\end{array}$ & $\begin{array}{c}95 \% \\
\text { CI }\end{array}$ \\
\hline Bio 5 & 43 & -0.038 & 0.002 \\
Bio 12 & 32 & 0.003 & 0.001 \\
Bio 16 & 22 & -0.009 & 0.004 \\
Bio 3 & 12 & 0.076 & 0.032 \\
Bio 13 & 11 & 0.039 & 0.011 \\
Bio 17 & 10 & 0.002 & 0.008 \\
Bio 15 & 9 & -0.029 & 0.006 \\
Bio 14 & 9 & -0.027 & 0.023 \\
Bio 18 & 7 & 0.003 & 0.001 \\
Bio 19 & 7 & 0.002 & 0.001 \\
Vegetation density & 6 & -0.011 & 0.003 \\
Bio 10 & 4 & -0.034 & 0.003 \\
Bio 9 & 3 & -0.011 & 0.006 \\
\hline
\end{tabular}

(Rödder et al. 2009, Liu et al. 2012, James et al. 2015, Becker et al. 2016). Although most of the $B d$ positive records overlapped with reported areas of high climatic suitability for the fungus in the Neotropics (Rödder et al. 2009, Liu et al. 2012, James et al. 2015, Becker et al. 2016), several Bd-positive records extend far into areas of poor suitability for $B d$ in anurans (e.g. central Amazon: see Becker et al. 2016). Our data points to widespread $B d$ infections in Neotropical caecilians, and that this taxon may serve as an environmental reservoir, perhaps because hosts are able to avoid harsh seasonal extremes where $B d$ would otherwise not persist yearround. These results, combined with a recent report of lethal chytridiomycosis in wild-caught caecilians (Gower et al. 2013), indicate that Gymnophiona are potentially experiencing silent population declines in the wild due to $B d$.

Spatial regressions are also consistent with the observed associations between macroclimate and $B d$ infection in anuran species (Becker \& Zamudio 2011, James et al. 2015, Becker et al. 2016). Specifically, we detected a positive effect of precipitation and a negative effect of temperature variables on the likelihood of $B d$ infection in caecilian hosts. Vegetation density, which is often positively associated with $B d$ infection in anurans (Raffel et al. 2010, Becker \& Zamudio 2011, Becker et al. 2012), showed a weak negative effect on $B d$ in caecilians. This finding might be due to the high degree of fossoriality of terrestrial caecilian species, which spares them from the direct or indirect effects of habitat quality, with downstream shifts in both macro- and microclimates. Elevation, which is often positively associated with $B d$ infection in anurans (Walker et al. 2010, Piovia-Scott et al. 2011, Gründler et al. 2012) due to optimal growth conditions in highlands (Piotrowski et al. 2004), showed no effect on $B d$ in Caecilians. Although our sampling spanned $1000 \mathrm{~m}$ in elevation, most of our samples were collected at lower altitudes. This uneven sampling across the elevation gradient may have thus impacted our ability to detect a significant effect of elevation in our analyses. Although large-scale climate may play a role in $B d$ epizootiology of caecilians, these results indicate that infection dynamics in caecilians and anurans might be different.

Although our results suggest that caecilians could act as pathogen reservoirs in environments or periods of harsh microclimatic conditions for $B d$, limited natural history information is available for most caecilian species (Gower \& Wilkinson 2005, Vitt \& Caldwell 2014). Basic information on foraging behavior, population densities, and breeding habits that would be key to quantifying transmission dynamics between Gymnophiona and Anura are typically lacking. It is known that 5 out of 10 families of caecilians are found in South America (Wilkinson et al. 2011, Frost 2016), and that these 5 families range from being obligate fossorial to completely aquatic (Haddad et al. 2013, Vitt \& Caldwell 2014). We predict that fossorial and fully aquatic species are less likely to be exposed to environmental and climatic fluctuations than terrestrial anurans because they spend longer periods of time underground or underwater. Future studies of caecilian foraging behavior and habitat use may help test the link between habitat use and temperature variability. Lower temperature extremes and variability are linked to higher $B d$ growth and persistence in amphibian hosts both in the wild and in the laboratory (Pounds et al. 2006, Raffel et al. 2013, 2015). Because $B d$ is a waterborne fungus (Longcore et al. 1999, Kilpatrick et al. 2010), we also expect fully aquatic caecilians to be exposed to the pathogen not only during their early life stages. Therefore, fossorial and aquatic life styles observed in caecilians are life history traits that likely make an efficient host reservoir, espe- 
cially in areas where $B d$ does not persist in anuran hosts year-round.

In areas of low predicted suitability for $B d$ such as the Amazon basin (Ron 2005, James et al. 2015, Becker et al. 2016), we detected an infection prevalence of $16 \%$, which is surprisingly high compared to the observed $\sim 3 \%$ in museum-preserved anurans in this region (Becker et al. 2016). In contrast, the proportion of infected caecilians in the Atlantic Forest was slightly lower than what has been observed for preserved anurans ( 23\%) in this ecoregion (Rodriguez et al. 2014). Nonetheless, limited sample sizes for caecilians prior to the 1970s precludes us from making any concrete spatio-temporal comparison between $B d$ in caecilians and in anurans from both the Atlantic Forest (Rodriguez et al. 2014) and the Amazon basin (Becker et al. 2016). Although most aquatic caecilians included in this study were sampled from the Amazon basin and most terrestrial caecilians from the Atlantic Forest, we did not detect a significant effect of host life style (aquatic vs. terrestrial) on the likelihood of $B d$ infection. These results further indicate that $B d$ infection dynamics in Gymnophiona might experience a lower pressure from macroclimate than in Anura.

Our results highlight an important gap in the study of amphibian chytridiomycosis: the possible impact of $B d$ on Neotropical caecilians and the hypothetical role of caecilians as $B d$ reservoirs. To date, information on the susceptibility of caecilian hosts to $B d$ infection is still lacking. Therefore, $B d$ genotypes detected in caecilians may present different adaptations to host histophysiology or microclimates, which provides a key opportunity to isolate and genotype new $B d$ isolates from live caecilians and test the virulence of these new isolates in anurans. Because $B d$ has a disproportionately higher impact in tropical amphibians, a better understanding of $B d$ infection dynamics in Gymnophiona may increase our knowledge about chytridiomycosis and advance our conservation efforts in the wild.

Acknowledgements. We thank Adriano O. Maciel, Alexandre F. R. Missassi, Manoela Woitovicz Cardoso, Nadya C. Pupin, and Tamilie Carvalho for help with swabbing and providing museum specimens. Ana L. C. Prudente (MPEG), Célio F. B. Haddad (CFBH), José P. Pombal Jr. (MNRJ), and Raúl Maneyro (ZVCB) allowed access to museum specimens. We thank David J. Gower and 2 anonymous reviewers for constructive feedback on our manuscript. This work was funded by Coordination for the Improvement of Higher Education Personnel (CAPES) and the National Council of Technological and Scientific Development (CNPq 405285/ 2013-2; 312895/2014-3) and the São Paulo Research Foundation (FAPESP 2014/23388-7).

\section{LITERATURE CITED}

Bataille A, Fong JJ, Cha M, Wogan GO and others (2013) Genetic evidence for a high diversity and wide distribution of endemic strains of the pathogenic chytrid fungus Batrachochytrium dendrobatidis in wild Asian amphibians. Mol Ecol 22:4196-4209

* Becker CG, Zamudio KR (2011) Tropical amphibian populations experience higher disease risk in natural habitats. Proc Natl Acad Sci USA 108:9893-9898

Becker CG, Rodriguez D, Longo AV, Talaba AL, Zamudio KR (2012) Disease risk in temperate amphibian populations is higher at closed-canopy sites. PLOS ONE 7:e48205

Becker CG, Rodriguez D, Lambertini C, Toledo LF, Haddad CFB (2016) Historical dynamics of Batrachochytrium dendrobatidis in Amazonia. Ecography 39:954-960

* Berger L, Speare R, Daszak P, Green DE and others (1998) Chytridiomycosis causes amphibian mortality associated with population declines in the rain forests of Australia and Central America. Proc Natl Acad Sci USA 95: 9031-9036

* Boyle DG, Boyle DB, Olsen V, Morgan JAT, Hyatt AD (2004) Rapid quantitative detection of chytridiomycosis (Batrachochytrium dendrobatidis) in amphibian samples using real-time Taqman PCR assay. Dis Aquat Org 60:141-148

Brem FMR, Lips KR (2008) Batrachochytrium dendrobatidis infection patterns among Panamanian amphibian species, habitats and elevations during epizootic and enzootic stages. Dis Aquat Org 81:189-202

* Catenazzi A, May R, Vredenburg VT (2013) High prevalence of infection in tadpoles increases vulnerability to fungal pathogen in high-Andean amphibians. Biol Conserv 159:413-421

* Cheng TL, Rovito SM, Wake DB, Vredenburg VT (2011) Coincident mass extirpation of neotropical amphibians with the emergence of the infectious fungal pathogen Batrachochytrium dendrobatidis. Proc Natl Acad Sci USA 108:9502-9507

* Churgin SM, Raphael BL, Pramuk JB, Trupkiewicz JG, West G (2013) Batrachochytrium dendrobatidis in aquatic caecilians (Typhlonectes natans): a series of cases from two institutions. J Zoo Wildl Med 44:1002-1009

* Courtois EA, Gaucher P, Chave J, Schmeller DS (2015) Widespread occurrence of $B d$ in French Guiana, South America. PLOS ONE 10:e0125128

* Doherty-Bone TM, Gonwouo NL, Hirschfeld M, Ohst T and others (2013) Batrachochytrium dendrobatidis in amphibians of Cameroon, including first records for caecilians. Dis Aquat Org 102:187-194

FAO (Food and Agriculture Organization of the United Nations) (2010) Global Forest Resources Assessment 2010, Main Report. FAO, Rome

* Fisher MC, Garner TWJ (2007) The relationship between the emergence of Batrachochytrium dendrobatidis, the international trade in amphibians and introduced species. Fungal Biol Rev 21:2-9

Frost DR (2016) Amphibian species of the world: an online reference. Version 6.0. American Museum of Natural History, New York, NY. Available at http://research. amnh.org/herpetology/amphibia/index.html (accessed on 23 August 2016)

Gower DJ, Wilkinson M (2005) Conservation biology of caecilian amphibians. Conserv Biol 19:45-55

Gower DJ, Doherty-Bone TM, Aberra RK, Mengistu A and others (2012) High prevalence of the amphibian chytrid 
fungus (Batrachochytrium dendrobatidis) across multiple taxa and localities in the highlands of Ethiopia. Herpetol J 22:225-233

*Gower DJ, Doherty-Bone TM, Loader SP, Wilkinson M and others (2013) Batrachochytrium dendrobatidis infection and lethal chytridiomycosis in caecilian amphibians (Gymnophiona). EcoHealth 10:173-183

Gründler MC, Toledo LF, Parra-Olea G, Haddad CFB and others (2012) Interaction between breeding habitat and elevation affects prevalence but not infection intensity of Batrachochytrium dendrobatidis in Brazilian anuran assemblages. Dis Aquat Org 97:173-184

Haddad CFB, Toledo LF, Prado CPA, Loebmann D, Gasparini JL, Sazima I (2013) Guia dos anfíbios da Mata Atlântica: diversidade e biologia. Anolisbooks, São Paulo

Hijmans RJ, Cameron SE, Parra JL, Jones PG, Jarvis A (2005) Very high resolution interpolated climate surfaces for global land areas. Int J Climatol 25:1965-1978

Hydeman ME, Bell RC, Drewes RC, Zamudio KR (2013) Amphibian chytrid fungus confirmed in endemic frogs and caecilians on the island of São Tomé, Africa. Herpetol Rev 44:254-257

James TY, Toledo LF, Rödder D, da Silva Leite D and others (2015) Disentangling host, pathogen, and environmental determinants of a recently emerged wildlife disease: lessons from the first 15 years of amphibian chytridiomycosis research. Ecol Evol 5:4079-4097

Kilpatrick AM, Briggs CJ, Daszak P (2010) The ecology and impact of chytridiomycosis: an emerging disease of amphibians. Trends Ecol Evol 25:109-118

Kriger KM, Ashton KJ, Hines HB, Hero JM (2007) On the biological relevance of a single Batrachochytrium dendrobatidis zoospore: a reply to Smith (2007). Dis Aquat Org 73:257-260

Labisko J, Maddock ST, Taylor ML, Chong-Seng L and others (2015) Chytrid fungus (Batrachochytrium dendrobatidis) undetected in the two orders of Seychelles amphibians. Herpetol Rev 46:41-45

Lambertini C, Rodriguez D, Brito FB, Leite DS, Toledo LF (2013) Diagnóstico do fungo quitrídio: Batrachochytrium dendrobatidis. Herpetol Bras 2:12-17

*Lips KR, Brem F, Brenes R, Reeve JD and others (2006) Emerging infectious disease and the loss of biodiversity in a Neotropical amphibian community. Proc Natl Acad Sci USA 103:3165-3170

Lips KR, Diffendorfer J, Mendelson III JR, Sears MW (2008) Riding the wave: reconciling the roles of disease and climate change in amphibian declines. PLOS Biol 6:e72

* Liu X, Rohr JR, Li Y (2012) Climate, vegetation, introduced hosts and trade shape a global wildlife pandemic. Proc R Soc Lond B Biol Sci 280:20122506

* Longcore JE, Pessier AP, Nichols DK (1999) Batrachochytrium dendrobatidis gen. et sp. nov., a chytrid pathogenic to amphibians. Mycologia 91:219-227

* Martel A, Spitzen-van der Sluijs A, Blooi M, Bert W and others (2013) Batrachochytrium salamandrivorans sp. nov. causes lethal chytridiomycosis in amphibians. Proc Natl Acad Sci USA 110:15325-15329

Ouellet M, Mikaelian I, Pauli BD, Rodrigue J, Green DM (2005) Historical evidence of widespread chytrid infection in North American amphibian populations. Conserv Biol 19:1431-1440

Penner J, Adum GB, McElroy MT, Doherty-Bone T and others (2013) West Africa - a safe haven for frogs? A subcontinental assessment of the chytrid fungus (Batracho- chytrium dendrobatidis). PLOS ONE 8:e56236

* Piotrowski JS, Annis SL, Longcore JE (2004) Physiology of Batrachochytrium dendrobatidis, a chytrid pathogen of amphibians. Mycologia 96:9-15

Piovia-Scott J, Pope KL, Lawler SP, Cole EM, Foley JE (2011) Factors related to the distribution and prevalence of the fungal pathogen Batrachochytrium dendrobatidis in Rana cascadae and other amphibians in the Klamath Mountains. Biol Conserv 144:2913-2921

*Pounds JA, Bustamante MR, Coloma LA, Consuegra JA and others (2006) Widespread amphibian extinctions from epidemic disease driven by global warming. Nature 439: 161-167

* Puschendorf R, Carnaval AC, VanDerWal J, Zumbado-Ulate H (2009) Distribution models for the amphibian chytrid Batrachochytrium dendrobatidis in Costa Rica: proposing climatic refuges as a conservation tool. Divers Distrib 15:401-408

Raffel TR, Michel PJ, Sites EW, Rohr JR (2010) What drives chytrid infections in newt populations? Associations with substrate, temperature, and shade. EcoHealth 7 : 526-536

Kaffel TR, Romansic JM, Halstead NT, McMahon TA, Venesky MD, Rohr JR (2013) Disease and thermal acclimation in a more variable and unpredictable climate. Nat Clim Chang 3:146-151

* Raffel TR, Halstead NT, McMahon TA, Davis AK, Rohr JR (2015) Temperature variability and moisture synergistically interact to exacerbate an epizootic disease. Proc R Soc Lond B Biol Sci 282:20142039

Rangel TF, Diniz-Filho JAF, Bini LM (2010) SAM: a comprehensive application for spatial analysis in macroecology. Ecography 33:46-50

Raphael BL, Pramuk J (2007) Treatment of chytrid infection in Typhlonectes spp. using elevated water temperatures. Proceedings of Amphibian Declines and Chytridiomycosis Conference, Tempe, AZ, 5-7 Nov 2007, p 37

Rendle M, Tapley B, Perkins M, Bittencourt-Silva G, Gower DJ, Wilkinson M (2015) Itraconazole treatment of Batrachochytrium dendrobatidis $(B d)$ infection in captive caecilians (Amphibia: Gymnophiona) and the first case of $B d$ infection in a wild neotropical caecilian. J Zoo Aquar Res 3:137-140

* Rödder D, Kielgast J, Bielby J, Schmidtlein S and others (2009) Global amphibian extinction risk assessment for the panzootic chytrid fungus. Diversity 1:52-66

Rodriguez D, Becker CG, Pupin NC, Haddad CFB, Zamudio KR (2014) Long-term endemism of two highly divergent lineages of the amphibian-killing fungus in the Atlantic Forest of Brazil. Mol Ecol 23:774-787

* Ruggeri J, Longo AV, Gaiarsa MP, Alencar LR and others (2015) Seasonal variation in population abundance and chytrid infection in stream-dwelling frogs of the Brazilian Atlantic forest. PLOS ONE 10:e0130554

* Savage AE, Grismer LL, Anuar S, Onn CK and others (2011) First record of Batrachochytrium dendrobatidis infecting four frog families from Peninsular Malaysia. EcoHealth 8: 121-128

* Seimon TA, Seimon A, Daszak P, Halloy SR and others (2007) Upward range extension of Andean anurans and chytridiomycosis to extreme elevations in response to tropical deglaciation. Glob Change Biol 13:288-299

Skerratt LF, Berger L, Speare R, Cashins S and others (2007) Spread of chytridiomycosis has caused the rapid global decline and extinction of frogs. EcoHealth 4:125-134 
Soto-Azat C, Clarke BT, Poynton JC, Cunningham AA (2010) Widespread historical presence of Batrachochytrium dendrobatidis in African pipid frogs. Divers Distrib 16:126-131

Talley BL, Muletz CR, Vredenburg VT, Fleischer RC, Lips KR (2015) A century of Batrachochytrium dendrobatidis in Illinois amphibians (1888-1989). Biol Conserv 182:254-261

Taylor EH (1968) The caecilians of the world: a taxonomic review. University of Kansas Press, Lawrence, KS

Valencia-Aguilar A, Ruano-Fajardo G, Lambertini C, da Silva Leite D, Toledo LF, Mott T (2015) Chytrid fungus acts as a generalist pathogen infecting species-rich amphibian families in Brazilian rainforests. Dis Aquat Org 114: 61-67

Vásquez-Ochoa A, Carmona PB, Salcedo LDP, Franco-Correa M (2012) Detección y cuantificación de Batrachochytrium dendrobatidis en anfibios de las regiones andina central, oriental, Orinoquia y Amazonia de Colombia. Herpetotropicos 8:13-21

Editorial responsibility: Lori Gustafson,

Fort Collins, Colorado, USA
Vitt LJ, Caldwell JP (2014) Herpetology. An introductory biology of amphibians and reptiles ( $4^{\text {th }}$ edn). Academic Press, San Diego, CA

* Vredenburg VT, Knapp RA, Tunstall TS, Briggs CJ (2010) Dynamics of an emerging disease drive large-scale amphibian population extinctions. Proc Natl Acad Sci USA 107:9689-9694

Walker SF, Bosch J, Gomez V, Garner TW and others (2010) Factors driving pathogenicity vs. prevalence of amphibian panzootic chytridiomycosis in Iberia. Ecol Lett 13: 372-382

*Weldon C, Du Preez LH, Hyatt AD, Muller R, Speare R (2004) Origin of amphibian chytrid fungus. Emerg Infect Dis 10:2100-2105

Wells KD (2007) The ecology and behavior of amphibians. The University of Chicago Press, Chicago, IL

Wilkinson M, San Mauro D, Sherratt E, Gower DJ (2011) A nine-family classification of caecilians (Amphibia: Gymnophiona). Zootaxa 2874:41-64

Submitted: September 1, 2016; Accepted: February 13, 2017 Proofs received from author(s): March 22, 2017 